\title{
Book review meets book club
}

\author{
Priscilla Alderson and Rachel Rosen \\ University College London Institute of Education
}

Reading seminars are an important aspect of the Childhood Studies courses at University College London (UCL). ${ }^{1}$ Often, students raise important questions and critiques during these 'book clubs', but their points remain unpublished. We decided to launch a project - 'book review meets book club' as a way of continuing critical dialogues about new texts and their relevance to students' work.

The first aim of the project was to encourage our students to consider writing book reviews, as there is a shortage of willing reviewers yet book reviews are often the most-read section in journals. Reviews are also very important for introducing and promoting critical dialogue about new books in the field. The second aim was to encourage students to learn about writing for academic publication, and writing a book review is a useful first step in becoming familiar with the process. We hoped to combine the rather isolated work of actually writing reviews with the support, encouragement, and elaboration of analysis through engagement with multiple viewpoints that a book club style of group discussion can offer.

We selected The Routledge International Handbook of Children's Rights Studies to review, as a book covering topics that appeal to the wide range of students invited to the 'book club'. The session began with an introduction to writing book reviews. ${ }^{2} \mathrm{~A}$ key topic we discussed was about the politics of academic publishing.

We advised our students that reviews should take into account the aims of the book and should be fair, explicit and honest. If the reviewer does not think the book is worth reading, it may not be worth writing a review, unless there are some important arguments for the reviewer to engage with. During the session we discussed the importance of framing critiques respectfully and carefully. One day, the reviewed author might be able to help or hinder the reviewer's own research and career. However, fear of being controversial can deter important criticism. Bland or glowing reviews can mislead readers and potentially everyone whom the readers might influence in future. And such reviews might also mislead librarians and lecturers into ordering mediocre and over-priced books. While a review is generally more engaging and effective if the reviewer gives an honest appraisal of the book's originality, relevance,

\footnotetext{
${ }^{1}$ Our courses include the MA in Sociology of Childhood and Children's Rights and a doctoral course: Doing Research with Children and Young People.

2 With thanks to Gareth Thomas and Rebecca Dimond, Review Editors of Sociology of Health \& Illness, for permission to adapt their note for reviewers.
} 
and contributions, we discussed that reviewers need to note the limits of their own knowledge.

During the session, the students had a chance to discuss their overall responses to the 23 chapter book, and a chapter of their choice, and we offered some suggestions as to how they might approach writing these up in a review. We hoped that through these discussions we could share our enthusiasms, challenge and advance each other's initial ideas, and think about how to clarify and extend our individual reflections.

A brief overview of the whole book is followed by students' reviews of specific chapters which resulted from the workshop.

\section{Routledge International Handbook of Children's Rights Studies By Wouter Vandenhole, Ellen Desmet, Didier Reynaert, and Sara Lembrechts (eds.) Abingdon: Routledge, 2015. ISBN: 9781138023703 , $436 \mathrm{pp}$, £131 (hb)}

\section{Priscilla Alderson \\ University College London Institute of Education}

The Handbook offers a critical multidisciplinary approach to children's rights studies drawing on law, history and social policy, sociology, social work, anthropology, geography, gender studies and citizenship studies, besides work on relations between children's rights and childhood studies. In the second part of the book, selected themes at the intersection of global and local concerns include critical reviews of children's rights in relation to Article 12 , to education, health, juvenile justice, formal alternative care, violence, female genital mutilation, work and labour, migration, global development, indigenous groups, and natural resources. Such diverse themes are drawn together in the editors' introduction and conclusion. The authors are based mainly in Europe with a few from North and South America.

The editors aim to address key challenges, and to consider 'bottom up' approaches to children's rights besides traditional 'top down' ones. The many authors examine debates between respecting children's freedoms but also protecting children and their usually adult-defined best interests. The chapters review differences, commonalities and unfortunate divergences between human rights and children's rights, as well as between universal rights based on social justice and respect for human dignity versus respect for local interpretations and traditions with the risk of sceptical relativism.

The introduction emphasises enduring uncertainties and debates about meanings of children, childhood and children's rights, and about how far children's individual interests can be reconciled with the family life on which most children depend. The editors contend that children's rights have to be understood within larger human rights and their common origins of respect for 
human dignity, albeit with respect for local contexts and diversities in globallocal interactions. The multidisciplinary collection explores specialised research on rights within each discipline yet with some engagement between disciplines. There is also concern to critique simplistic and dogmatic practical attempts to promote children's rights, which lack critical reflection and research on the actual problems and proposed remedies being addressed. These criticised attempts include, for example, new laws or school councils, which very often achieve little practical change.

The editors' conclusion reviews all the chapters in detail, drawing out common themes. It ends with four 'fundamental starting points' for children's rights studies: to relate universal principles to practices including the broader local-global social context and the life-worlds, norms and values influencing children's lives; to relate children's rights to the all-age human rights that enshrine dignity and justice; to analyse children's own contributions to knowledge and action about rights; and to maintain constant critical interdisciplinary analysis of children's rights and the goals of emancipation and transformation.

The Handbook's widely varying chapters and thoughtful analyses offer much of value to students, lecturers, researchers and activists concerned with children's rights. My own view is if the authors had drawn on critical realism they could have clarified many uncertainties. These include unresolved questions and dualisms about whether universal rights are drawn from timeless principles of justice, equity and freedoms from oppression, and they really independently exist, or else are rights contingent fluid local social coconstructions as, for example, Stuart Aiken (2016) and others propose.

Difficulties arise when rights that are denied are assumed not to exist at all, whereas rights as claims and remedies for wrongs become most urgent and important when they are denied. Critical realism analyses dynamic interactions between universal rights and their local interpretations, without having to deny either reality, through the dialectics of structure and agency, local and global, absence and presence, and processes of transformative change (as analysed, for example, in Alderson, 2013, 2016).

\section{References}

Aiken, S. (2016) Children's rights: a critical geographic perspective, in Vandenhole et al. (eds) The Routledge International Handbook of Children's Rights Studies, London: Routledge, pp. 131-146.

Alderson, P. (2013) Childhoods Real and Imagined: Practical Application of Critical Realism and Childhood Studies, Volume 1. London: Routledge. Alderson, P. (2016) The Politics of Childhoods Real and Imagined: Practical Application of Critical Realism and Childhood Studies, Volume 2. London: Routledge. 


\title{
Children's rights from a legal perspective: Children's rights law, Chapter
} 2 By Woute Vandenhole, pp. 27-42.

\author{
Maria Tatti, MA student \\ University College London Institute of Education
}

This brief review summarises the main topics of Chapter 2, and specifically the three substantive themes in children's rights. The chapter draws on international law at global and regional levels including the UNCRC, the African Charter on the Rights of the Child, the European Convention on Human Rights, the 2007 European Convention on the Exercise of Children's Rights and others, which provide a legal framework in regard to the rights of children as well as the responsibility of the state, the school, the educators and the parents or guardians.

Specifically, the chapter provides a framework of the strengths and limitations as well as a critique of these instruments and laws, providing the reader with a clear legal understanding of children's rights. The language is clear and easy to understand and the reader is eased into the main body of the text. The arguments are clearly presented and no previous knowledge in the field is required. The second part of the chapter "General obligations and principles" mainly focuses on the UNCRC, in order to present the ratified obligation of the state parties as well as to highlight the principles which inform children's rights law.

The third part of the chapter, "Some themes" mainly based on the European Court of Human Rights, discusses three themes in children's rights: juvenile justice, family and alternative care and education. The first theme presents the basic principles of children's rights in juvenile justice, specifically the UNCRC rights to freedom, infringement of penal law, reintegration, rehabilitation and related rights. Case-law, such as by the European Court of Human Rights, covers the length of a prisoner's detention, the failure of the authorities to provide the necessary medical treatment for prisoners' possible psychological conditions including attempts to commit suicide. The minimum age of criminal responsibility, the importance of accused persons' access to a lawyer, and the reintegration of the individual into the society, following their release, was also discussed. The second theme "Family and alternative care", based on the UNCRC and case-law of the European Court of Human Rights, discusses children's right to respect for family life, to protection against separation from their family against their will, to the responsibility of the parents for the development of the child as well as to the obligation of the state to take appropriate measures to protect children against violence.

The third theme "Education" considers the rights of all children to education regardless of their status in a range of UN treaties. The author argues that education not only benefits those who receive it but also the society more 
broadly. The right of children with disabilities, Roma children and children of migrants to education was also discussed.

The chapter provides a good base for the reader to challenge dominant perspectives on children's rights. In particular it moves beyond the issue of implementation of children's rights and points to the need for individuals and the state to challenge the way children's rights are approached. The author refers to a 'bottom up' approach, which gives the opportunity for the everyday experiences of children to be articulated rather than relying on a more adultdriven approach. In such an approach, children's rights are practices that emerge from everyday realities as well as from different contexts and therefore require contextualisation as well as localization.

\title{
Education and Children's Rights, Chapter 12 by Ann Quennerstedt, pp.
} 201-215.

\author{
W'Ayendjina Gina Antchandie, graduate MA Sociology of Childhood and \\ Children's Rights \\ University College London Institute of Education
}

Quennerstedt aims to clarify the complexity of the relations between education and children's rights from an educational perspective. She uses a framework not dissimilar to Tomasevski's (2006) 4As (Availability, Accessibility, Acceptability and Adaptability) to explore the right to education and rights in education. Research studies are mentioned throughout the paper as examples in support of her main points. Quennerstedt first argues that the right to education is not solely a right to access education but should also include the quality of educational content and processes, as outlined in international human rights instruments. She stresses the confusion about the entitlement itself in international treaties which refer to pre-primary, primary, basic or secondary levels. In this section, school choice, segregation in education and the right of migrants' children are all highlighted as unresolved in matters of access and poor quality of educational content.

The author then moves on to rights in education, advocating the respect of children as human rights holders through the choice of educational content, the teaching and practice of values reflecting human rights in schools, and the educational processes promoting human rights. In particular, experiencebased learning and participation are singled out as valuable educational processes from a rights-perspective. This section also draws attention to the unequal power dynamics between teachers and students, as the image of the child as 'becoming' still prevails in educational settings. When turning to peer relations, a human rights framework is recommended to combat bullying and discrimination. 
Despite a seemingly comprehensive overview of the proposed subject, there are a number of concerns with this chapter. The introduction is largely overstated and lacks in nuanced definitions of key terms. Particularly it would have been helpful, in a paper that proposes to tease out the complex relations between education and children's rights, to give a justification for education as a human right - other than 'education is regarded high enough to declare it a human right' (p. 201). The intrinsic value of education is overlooked in favour of an instrumental value which puts education down as an individual and societal good. With the intrinsic value ignored, it becomes more difficult to provide a rationale for education as a human right. In addition, the question on 'the meaning of the right' (p. 204) is uncritically limited by the designated levels (for example, primary, basic) imposed, for pragmatic purposes, by the international human rights community. If indeed it is a human right, education would be expected to be life-long.

It is also debatable whether the 'access and content'/ 'content and relations' dyad used by the author actually adds to the well-publicised framework of Tomasevski's 4As. Despite drawing explicit attention to the generational and peer relations within educational settings, the chapter would easily fit into the first 3 As, and noticeably omits the final A, Adaptability, which addresses diverse childhoods and the relevance of education beyond the confines of schools. The right to education in this chapter is restricted to education in formal educational settings, and, in particular, to academic education. This conflation narrows down the nature, meaning, and conceptualisation of the right. It devalues other forms of education and excludes children who do not attend school (or at least not full-time). The chapter advocates experiencebased learning as a valuable educational process in schooling, but makes no reference to working children and traditional skilled trades in the majority world. It promotes the schooled child as the universal norm declaring 'For children and young people, education is life in all its facets' (201) reinforcing the idea of children as 'tabula rasa'. Such overstatements close the door to further exploration of multiple childhoods and are decisively misleading in a handbook of children's rights studies which claims to be international.

Perhaps the biggest concern is the lack of engagement with the context. There is very little value for children (and students in children's rights studies) in a piece that treats education as an 'abstract entitlement' (p. 202) and overlooks the multiplicity of childhoods. How can we justify writing or presenting a piece on education and children's rights without establishing a dialogue with the context, without accounting for the effects of a global neoliberal agenda on the right itself, on the prevalence of human capital theory in educational settings, and on the lives of children? The author's final call for critical reflection may be an attempt to somehow correct these shortcomings, but it comes far too late. An engagement with other chapters of this handbook focussing on the impact of global processes on children's daily lives (for instance chapters 8 A critical geographic perspective, and 20 on 
global child poverty) might have helped to prevent this oversight. The chapter would have benefited from an integrated and applied critique throughout rather than a final section which, unfortunately, looks more like a last-minute add-on.

This might be something for the editors to consider, particularly in view of their avowed aims to move towards inter-disciplinary critical children's studies.

\section{References}

Tomasevski, K. (2006) Human Rights Obligations in Education: The 4-A Scheme. Oisterwijk: Wolf Legal Publishers and the European Association for Education Law and Policy.

Health and Children's Rights, Chapter 13 By Ursula Kilkelly pp. 216-233.

Rosa Maria Mendizabal-Espinosa, PhD student University College London Institute of Education

Through this chapter, Ursula Kilkelly addresses children's different activities in their own health and healthcare. She begins by providing an overview of the UNCRC provision on the right to healthcare, and a brief review on the guidance of the Committee of the Rights of the Child (2009). By discussing UNCRC articles 2, 3, 5, 6, 12 and 24, the author shows how the UNCRC manages to embrace healthcare for children that is informed by equitable access, the best interests of the child and children's views and perspectives (p. 220). At the same time, she identifies gaps and omissions, which work to the detriment of enjoyment of the highest attainable standard of health.

Three contemporary challenges to child health are identified by Kilkelly. The first one is that of consent. The age/capacity dichotomy is problematized here in what I found to be a contradictory form. On the one hand she critiques the UNCRC for not addressing what she proposes to be 'arguably the key question in child health' (p. 221), namely the minimum age when children can consent (or refuse) to treatment without the consent of their parents or carers. On the other hand, she describes the gradual shift in the awareness of children's competency and capacity, where understanding has started to be more relevant than age. In the end, there is no clear indication on what Kilkelly's position in the matter is.

Sexual health and health promotion are named as the other two challenges. On the former, the very complex situation of children becoming mothers is considered. Autonomy over their body and in decision-making, access to family planning and safe abortion services are raised but unfortunately not discussed further.

The last two sections analyse the opportunities and difficulties in the implementation of children's rights to participate in healthcare decision- 
making, policy-making and service design. Special consideration is given to the relationship between health professionals, parents and children. The voices of children resonate in the variety of examples used by the author, although mainly from projects developed in the UK and Ireland. Kilkelly makes a call to go beyond recording children's views and to actively support them in engaging in service organisation, governance and policy formulation' (p. 227).

This chapter opened by pointing at global factors that impact on children's access to health: deficient healthcare systems, poverty, famine and drought, to name a few. Migration and armed conflicts could be added to this list. The author also reminds us that child mortality is still one of the main challenges in some areas of the world. There is no doubt these problems are very complex, probably out of the author's, and indeed out of this reviewer's expertise. However, in a book that aims at 'taking a critical approach to children's rights' (as is the title of the introduction p. 1), it is unfortunate that Kilkelly did not consider further how all these factors affect children's active involvement and participation in matters of their own health.

I found this chapter informative, well written and enjoyable to read. Yet, it leaves me with the feeling that something is missing. Perhaps this is due to my particular interest in the health of babies. I approached this reading with the hope of finding an analysis that was inclusive of all children, not only of the ones who can express their views through words. Or perhaps it is the fact that I was born and raised in a 'developing country' that I found it difficult to connect with experiences portrayed throughout this chapter. Certainly, an 'international' book promised more than the usual 'Europe Centred' approach.

\section{References}

UN Committee of the Rights of the Child (2009) The Right of the Child to be Heard. General Comment 12. Geneva: UNCRC.

\section{The human rights of children in the context of international migration, Chapter 19 By Pablo Ceriani Cernadas, pp. 331-356.}

Sandra Marie El Gemayel, PhD student

University College London Institute of Education

This chapter tackles particularly topical and relevant problems in today's world. Ceriani presents five categories of children in connection with migration: 'Unaccompanied and separated children', 'children who migrate with their families', 'children left behind by migrant parents', 'children born to migrant parents in host countries', and 'returned and deported children'. He discusses some of the main causes of migration in relation to globalisation. He then analyses international standards and the key challenges and 
shortcomings to honouring children's rights in the context of migration, presenting his view on how children's rights should be applied in such cases.

The topic is unpicked in a way which is accessible to people from any academic discipline, not only experts in law or migration studies. Ceriani's use of terms specific to his field is promptly followed by clear definitions and examples, allowing readers to better follow his critique of the integration of the CRC into child migration policies and practices. That being said, the term migrant is a hotly debated one. Although Ceriani notes that some reasons for migration are survival, security, and protection from abuse or violence, he does not explicitly define the meaning of the term for the purpose of the chapter, or state whether the term includes refugees and asylum seekers or not. Nonetheless, Ceriani clearly meets the aims which he sets out at the beginning of the chapter, looking critically at the reality and implementation of child migrants' rights, aiming to come up with new proposals and ideas on children's rights in relation to international standards and principles, giving his readers a clear understanding of the gaps between the UNCRC and migration policies and practices, and explaining how relevant public policies affect these children's rights.

Furthermore, while Ceriani describes the situation of children's rights in relation to child migrant policies and proposes how these policies may be amended in order to better incorporate those rights, it remains a fact that implementation of these policies is not a guarantee. This chapter could be built on to propose ways of implementing these policies and ensuring their enforcement worldwide, depending on the individual case of each country, whether it be a country of origin, transit or destination. In addition, amending policies to incorporate children's rights does not necessarily ensure high quality provisions or even children's access to these provisions. For example, a policy may approve schooling for all children, regardless of nationality or status in the country, however children's requirement to work (due to irregular status of parents or poverty), hard barriers (costs of travel to school, books and uniform, registration) and soft barriers (inability to keep up with the curriculum, bad quality education) (REACH Initiative \& United Nations High Commissioner for Refugees, 2014) may impede and make the implementation of this policy impossible for both documented and undocumented children. It is also important to consider that not all countries fulfil the human rights of their own people. Ignoring the needs of a country's own people while offering support to migrants may lead to even greater tensions and resentment between nationals and migrants, fuelling discrimination on a social level.

Finally is the great importance that Ceriani places on children's rights and their integration and implementation into the process of migration, whether it be in migration policies or in training those who work with children (legal advisors, guardians, or authorities in charge of facilities). All this should undoubtedly be implemented, seeing that until very recently, children 
remained largely invisible in the context of international migration. By placing children's rights within the broader framework of human rights, Ceriani shows how the implementation of parents' or guardians' human rights in turn leads to the fulfilment of the child's rights, highlighting the inter-relational aspect of rights. Consequently, by portraying the importance of family and community in child migration policy, it may be possible to meet the human rights of the whole community.

\title{
References
}

REACH Initiative, \& United Nations High Commissioner for Refugees. (2014). Barriers to Education for Syrian Refugee Children in Lebanon: Out of School Children Profiling Report. Lebanon. Retrieved from www.reachresourcecentre.info

\section{Indigenous children's rights: Opportunities in appropriation and transformation, Chapter 21 By Natasha Blanchet-Cohen, pp. 371-386.}

\author{
Haseena Noushad, MA student, \\ University College London Institute of Education
}

Many children do not fit into the mainstream norms in society, none less so than children from Indigenous communities throughout the world. Chapter 21 introduces the rights that Indigenous children have under the UNCRC. As a Master's student, I was very pleased that the book included a chapter on Indigenous children, as many Indigenous people a have a long history of living sustainably with the land, which is something that needs to be valued by everyone to protect the environment for future generations. The chapter ( $p$. 374) refers to UNICEF highlighting that 'indigenous children carry with them a reserve of knowledge that is their special inheritance, and from which we can all benefit'. The chapter may inspire students to be a part of the 'Indigenous movement' (p. 375) to raise awareness of Indigenous people and in particular the promotion of rights of Indigenous children who are the future custodians of Indigenous traditions and knowledge. Indeed, the chapter (p. 375) notes that 'when indigenous people WIN, the whole world WINS'.

The chapter aims to build a picture of the many problems faced by Indigenous people of discrimination and exclusion, which the UNCRC addresses. These include the impact of colonialism on their lives and the difficulties they face in integrating into societies that do not necessarily embody their own way of living. In fact the chapter emphasizes that it took over twenty years of consultations to agree on the rights of Indigenous people within the United Nations (2007). This highlights the struggles that Indigenous people face when other stakeholders have such vested interests not only in 
destroying their way of life but also in taking away the very resources that they depend on to live their lives. The chapter identifies the discrimination against Indigenous children; for example, many do not have birth certificates, which can cause problems in terms of confirming their identities and can subsequently lead to delays in processing their paperwork. The chapter questions why many population surveys exclude Indigenous people as a category. Do they not exist or matter? Furthermore, many rights of Indigenous people are violated consistently and they rely on others to support them in their continual struggle to survive.

However, Indigenous children are getting involved by challenging their own people into accepting children's involvement throughout their community and not just in areas designated for children. Indigenous children face many difficulties in the education system through a lack of resources available to support their own culture. The acquisition of new cultures and languages through education can also conflict with their own identities. Yet as the chapter asserts, Indigenous children cannot rely on their culture alone but also often need to be employable in wider society to survive. Indigenous children, their people and their supporters are fundamental to the implementation of the UNCRC. The chapter reiterates that it is by being involved that the Indigenous children can make a difference to their lives. The reader is drawn into the world of the Indigenous people through their own words, although I would have preferred to hear more from Indigenous children themselves. I would have also liked more detailed information on a few specific Indigenous groups rather than skimming over many.

However, these few points aside the chapter creates a potted version of the history of the rights of Indigenous children which should be an excellent starter to whet the appetite for further research into this very important area of human existence. Students of human rights, sociology, law, anthropology and history are amongst those that this chapter would be of special interest for.

\section{Reference}

United Nations. Declaration on the Rights of Indigenous People, New York: United Nations, 2007. 